DOI: https://doi.org/10.32838/2523-4803/70-3-15

УДК 338.436

\title{
Саковська О.M.
}

кандидат економічних наук, доцент,

доцент кафедри туризму та готельно-ресторанної справи,

Уманський національний університет садівництва

ORCID: https://orcid.org/0000-0003-2676-6170

\section{Sakovska Olena}

Uman National University of Horticulture

\section{СТАН ТА ПЕРСПЕКТИВИ РОЗВИТКУ СІЛЬСЬКОГОСПОДАРСЬКИХ КООПЕРАТИВІВ ЧЕРКАСЬКОЇ ОБЛАСТІ}

У статті проаналізовано стан, специфіку та перспективи розвитку сільськогосподарських кооперативів Черкащини. Зазначено, щзо за сучасних економічних умов об'єднання товаровиробників на умовах кооперації набуває особливої актуальності. Встановлено, щзо основними иілями розвитку сільськогосподарської кооперації на території Черкащчини є створення сприятливих соціально-економічних умов для розвитку інфраструктури села, удосконалення системи заготівлі продукції, переробки сільськогосподарської продукиії. Встановлено, щчо в області здійснюється комплексний підхід до розвитку кооперації, який включає державні, організачійні, фінансові механізми та об'єднання зусиль всіх рівнів влади. Окреслено принципові засади розвитку сільськогосподарських кооперативів на території Черкаської області. Розроблено систему управління розвитком кооперації на регіональному рівні. Визначено ключові заходи державної підтримки сільськогосподарської кооперації в області та досліджено шляхи їх реалізації. Вказано, щчо результатом застосування комплексних заходів державної та регіональної підтримки сільськогосподарської кооперації має стати підвищення рівня довіри сільського населення до кооперативних форм господарювання.

Ключові слова: кооператив, сільське господарство, сільська територія, регіон, держава, розвиток.

Постановка проблеми. Сільськогосподарська кооперація є однією з ключових складових частин забезпечення продовольчої безпеки України та відіграє значну роль у зміцненні економічного потенціалу регіону, поліпшенні умов господарювання та створенні стимулів для зростання товарної продукції.

Кооперативні підприємства становлять основу розвитку сільських територій та відіграють провідну роль не тільки у прискоренні темпів росту агропромислового комплексу, а й у вирішенні найважливіших соціальних завдань села: забезпечують зайнятість сільського населення; сприяють збереженню традиційного способу життя; є джерелом наповнення місцевих бюджетів. Тому одним із пріоритетних напрямів розвитку економіки України є відродження та сталий розвиток системи сільськогосподарської кооперації. Вказаний аспект зумовлює актуальність статті, окреслює мету та завдання дослідження.

Аналіз останніх досліджень і публікацій. Ідеї кооперації були предметом дослідження багатьох вчених, зокрема слід виділити праці А. Арсьонової [2], В. Зіновчука В. [3], К. Кучерявої [4]. Свої праці вирішенню проблемних питань зі створення, розвитку та організації діяльності кооперативів присвятили: Ю. Лузан [7], М. Малік [1; 7], В. Русан [8],
О. Собкевич [8], Ю. Ушкаренко [13], А. Чмут [13], О. Шпикуляк $[1,13,14]$, А. Юрченко [8] та інші. У працях згаданих авторів розглядаються деякі аспекти розвитку та формування сільськогосподарської кооперації, зокрема: використання земельних ресурсів 3 метою розвитку сільськогосподарських кооперативів, чинники та процеси розвитку кооперації тощо. Водночас питання вивчення основних принципів інноваційного розвитку та підтримки кооперативного руху на рівні окремих територій нині є малодослідженими, а тому зумовлюють тематику та напрям дослідження.

Формулювання цілей статті. Мета роботи полягає в аналізі стану та визначенні ключових принципів розвитку сільськогосподарських кооперативів Черкащини.

Зважаючи на мету статті, головним завданням дослідження є визначення принципових засад розвитку сільськогосподарських кооперативів на території Черкаської області.

Об’єктом дослідження є державна та організаційноекономічна система розвитку сільськогосподарських кооперативів Черкащини.

Предметом дослідження виступає сукупність теоретичних, методичних і практичних підходів до розвитку сільськогосподарської кооперації. 
У процесі дослідження для визначення ключових принципів розвитку, ролі та місця сільськогосподарської кооперації у секторі сільського господарства Черкаської області було використано такі методи: економіко-статистичний, аналітичний, абстрактно-логічний, монографічний, а також відповідні їм прийоми. Вивчено зарубіжний і вітчизняний досвід розвитку сільськогосподарської кооперації, проаналізовано діючу систему розвитку кооперації в регіоні.

Виклад основного матеріалу дослідження. У сучасних умовах об'єднання товаровиробників на умовах кооперації набуває особливої актуальності.

Кооперація відкриває для невеликих сільськогосподарських підприємств можливість нарощувати виробництво власної продукції, отримувати допомогу від держави під час купівлі техніки, здійснювати обробку землі інноваційними техніко-технологічними методами та засобами, розширювати ринки збуту та реалізації продукції тощо [1, с. 74]. У підсумку це впливає на підвищення доходів і рівня життя людей, слугує важливим фактором забезпечення зайнятості населення, розвитку сільськогосподарських територій i вирішення нагальних соціальних проблем. Одними iз причин поглиблення проблем розвитку сільського господарства $є$ недостатнє бюджетне фінансування, низька участь держави у регулюванні аграрного ринку та його нерозвинена інфраструктура [2].

Недостатня ефективність роботи сільськогосподарських кооперативів пов'язана як із низьким рівнем державної підтримки, так і з відсутністю зацікавленості у створенні кооперативів самими сільськогосподарськими товаровиробниками [3, с. 46]. Вирішення питання розвитку сільського господарства можливе за умови підтримки розвитку мережі кооперативів як важливого соціально-економічного чинника підвищення ефективності сільськогосподарського виробництва на обласному, районному рівнях, а також шляхом залучення інвестицій, що сприятиме активному розвитку сільських територій та підвищенню рівня і якості життя сільського населення загалом [4, с. 35].

Сільськогосподарська кооперація покликана стати одним з основних інтеграційних інструментів аграрного сектору Черкаської області. Агропромисловий комплекс Черкащини є одним із системоутворюючих секторів економіки області, що формує агропродовольчий ринок, продовольчу і економічну безпеку регіону. У січні-червні 2019 р. індекс виробництва валової продукції сільського господарства по всіх категоріях господарств сягнув 104,5\%. Це - 9 місце поміж усіх областей (по Україні - 105,8\%), зокрема в сільгосппідприємствах - 106,6\% [5].

Цілями розвитку сільськогосподарської кооперації на території Черкащини є: створення сприятливих соціально-економічних умов для розвитку інфраструктури села, удосконалення системи заготівлі продукції, переробки сільськогосподарської продукції. Станом на 30 січня 2019 р. в Черкаській області зареєстровано 128 сільськогосподарських обслуговуючих кооперати- вів. Найбільше зареєстровано багатофункціональних кооперативів - 78. Ще 21 - заготівельно-збутових, 9 переробних та 20 - іншої спрямованості. Лише 2018 р. на Черкащині створили 17 кооперативів [5].

Розвиток кооперативного руху на Черкащині залишається серед пріоритетних та $є$ напрямом реалізації Стратегії розвитку-2020. За першу половину 2019 р. в області розпочали свою діяльність більше 10 сільськогосподарських обслуговуючих кооперативів. Це переважно універсальні, які спеціалізуються на наданні членам кооперативу послуг з обробітку земельних ділянок, транспортних, заготівельних та інших. Крім того, основний напрямок фінансової підтримки спрямовано на створення нових та підтримку діючих молочарських кооперативів. Об'єднання у такі кооперативи дасть можливість отримати суттєву державну допомогу на відшкодування закупленого обладнання за державними програмами. Найбільше створено кооперативів у Черкаському (19) та Лисянському (13) районах. Ще по 11 кооперативів діє на Катеринопільщині, Монастирищині та Смілянщині [6].

Процес розвитку системи кооперації в Україні йде шляхом формування багаторівневої і відкритої системи $[7$, c. 5]. При інтенсивному розвитку цього процесу у сфері сільського господарства створюється багаторівнева система, що виходить за іiі межі і проникає в інші галузі - переробки, торгівлі, виробничого сервісу, поставок ресурсів для сільгоспвиробників. Як будьякий бізнес-проект, кооператив вимагає від кожного учасника готовності вкладатися в майбутній успіх, зокрема робити фінансові інвестиції [8].

Збільшенню числа сільськогосподарських кооперативів в області сприяє ефективно діюча трирівнева система управління розвитком кооперації «область - район - село (або ОТГ - об'єднана територіальна громада)» і активна робота інститутів розвитку кооперації (рис. 1).

В області здійснюється комплексний підхід до розвитку кооперації, який включає організаційні, фінансові механізми та об'єднання зусиль всіх рівнів влади. Створена в Черкаській області комплексна система розвитку кооперації спрямована на розвиток сільських територій і передбачає:

- забезпечення зайнятості сільського населення шляхом залучення особистих підсобних господарств у товарне виробництво;

- поліпшення якості життя сільського населення через підвищення прибутковості шляхом участі в кооперативної діяльності.

У кожному селі чи ОТГ визначено відповідальних координаторів, в основному це очільники сіл (голови ОТГ), а в районі організовано координаційні центри. Інституціями 3 успіху розвитку кооперації в області стали регіональний фонд підтримки підприємництва по Черкаській області, Фонд підтримки кооперативів, районні Центри розвитку кооперативів.

Прикладом підтримки системи кооперації на регіональному рівні $є$ реалізація проекту «Створення регіонального навчально-практичного центру розвитку 


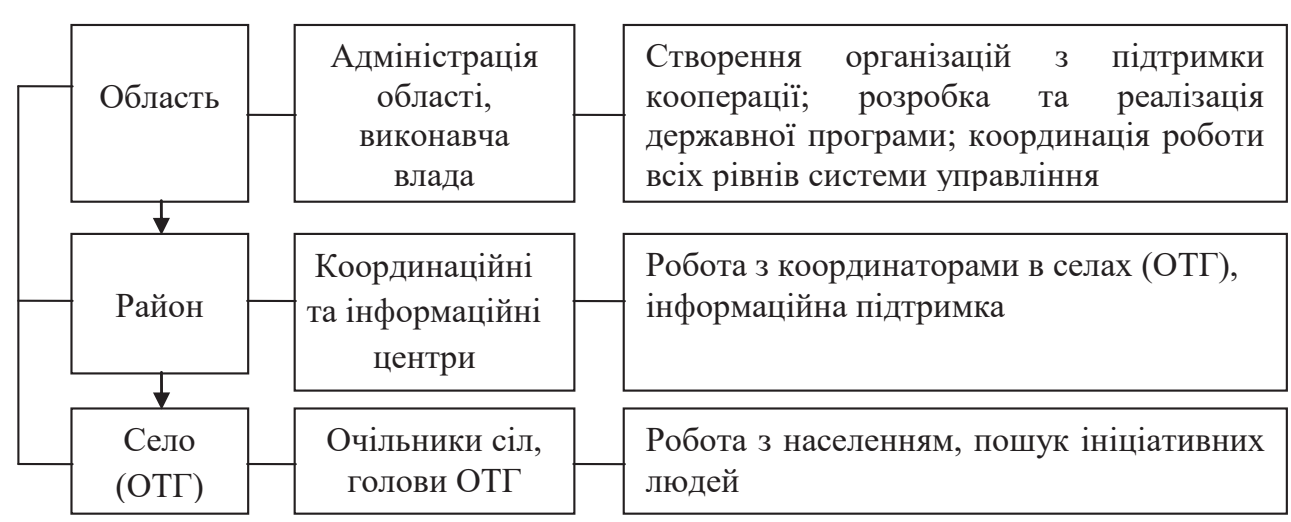

Рис. 1. Система управління розвитком кооперації на регіональному рівні

Джерело: створено автором на основі проведеного дослідження

багатофункціональних кооперативів», фінансування якого підтримується Свропейським Союзом у рамках програми ЄС «Підтримка політики регіонального розвитку в Україні». Вартість проекту - 617137,30 євро. Внесок СС - 79,97\% від загальної вартості проекту становить 491925,30 євро. Співфінансування від Черкаської обласної ради (за рахунок коштів місцевих бюджетів) - близько 20\% та становить 123212,0 євро. Проект стартував у січні 2015 р. (термін 30 місяців). Партнери проекту - Черкаська обласна рада та Ресурсний центр АНГО.

Проектом передбачено створення комунального підприємства «Регіональний навчально-практичний центр розвитку багатофункціональних кооперативів». Першочерговою ціллю Центру розвитку стало розведення племінного поголів'я кролів 3 послідуючою передачею сільськогосподарським обслуговуючим кооперативам 3 метою поширення в області кооперативного руху та збільшення робочих місць на селі.

У Центрі розвитку новостворені та діючі кооперативи можуть отримувати юридичний, ветеринарний, зоотехнічний, бухгалтерський, управлінський та інший супровід своєї господарської діяльності. Це дасть можливість додатково залучити кошти у розвиток сільських територій регіону, створити нові робочі місця, підвищити рівень доходів сімей - членів кооперативу, підвищити рівень якості та асортимент продукції місцевого виробництва, покращити соціально-економічну ситуацію в області.

Функціонування Центру розвитку спрямовано на:

- методичну та консультативну підтримку діючих та потенційних членів кооперативів;

- навчання та стажування діючих та потенційних членів кооперативів щодо передачі ефективних методів господарювання та управлінських навичок;

- матеріальну підтримку діючих кооперативів, які планують диверсифікувати свою діяльність, та ініціативних груп, що планують створити нові види кооперативів, шляхом передачі їм в користування обладнання, селекційного матеріалу тощо;

- використання найкращого вітчизняного і зарубіжного досвіду функціонування кооперативів;
- розширення можливостей для розвитку кооперативного руху шляхом проведення спеціалізованих семінарів, науково-практичних конференцій тощо;

- об'єднання та консолідацію сил та кооперативів області навколо створення належних умов для підвищення добробуту сільського населення та розвитку сприятливих можливостей сільських громад.

Також Проектом проводяться навчання, так, зокрема вже проведено 20 інформаційних семінарів для 400 осіб; навчальних семінарів (стажування) для 200 осіб; прес-тур для журналістів та інші заходи. У результаті реалізації Проекту планується створити щонайменше 50 нових сільськогосподарських обслуговуючих кооперативів, залучити близько 1000 громадян до господарської діяльності та працевлаштувати близько 300 осіб на селі. Кооперативи отримають матеріально-технічну підтримку через передачу в користування спеціального обладнання та матеріалів.

Таким чином, на основі реалізації проекту «Створення регіонального навчально-практичного центру розвитку багатофункціональних кооперативів» покращиться соціально-економічна ситуація в сільській місцевості та на продовольчих ринках області за рахунок збільшення якісної сільськогосподарської продукції за доступними цінами [9].

У межах обласної програми підтримки розвитку сільськогосподарських обслуговуючих кооперативів (СОК) Черкащини в обласному бюджеті на 2020 р. передбачено 2 млн грн для їх фінансової підтримки на умовах співфінансування. Ці кошти спрямовано на фінансування на придбання нового обладнання для розширення виробництва чотирьох кооперативів області. Вироблення сирів, розведення биків, скотарство - саме у цих галузях працюють СОКи, яким спрямують кошти на розвиток у межах обласної програми.

Кошти спочатку отримають РДА, звідки їх перенаправлять уже безпосередньо сільськогосподарським кооперативам. Зокрема, Монастирищенській РДА спрямують для фінансової підтримки СОК «Агроселбуд» 210 тис. грн та СОК «Бики Черкащини» майже 721 тис. грн; Смілянській РДА для фінансової підтримки СОК «Сміляночка» - 303 тис. грн; Звениго- 
родській РДА для фінансової підтримки СОК «Дружба плюс» - 692 тис. грн. Усіма кооперативами документально обгрунтовано потребу та підтверджено свою готовність освоїти виділені їм кошти на розвиток власної справи.

Єдиний в Україні сільськогосподарський обслуговуючий кооператив, який діє в селі Цибулів, «Бики Черкащини», у межах програми має намір закупити обладнання загалом на понад 1 млн грн. Насамперед підприємство потребує ваги, молочну кухню й таксі.

Майже 1 млн грн на закупівлю обладнання спрямують до кооперативу з виробництва сирів «Дружба», що у селі Неморож Звенигородського району. Кооператив спеціалізується на виробництві сирів Гауда та Рікотта, масла, м'яких сирів, маскарпоне під торговою маркою «Family cheese». Продукція кооперативу сертифікована за європейськими стандартами. Реалізують їі здебільшого у Вінницькій, Одеській областях. Нині працюють над тим, аби вийти на торговельні майданчики Черкас. За день кооператив може перебити до тонни молока. Придбавши ж нове обладнання, кооператив матиме змогу збільшити ці потужності до 3-4 тонн. Це ж сприятиме і збільшенню робочих місць у кооперативі.

На розвиток ще одного молочарського кооперативу зі Смілянщини «Сміляночка» планується спрямувати 435 тис. грн.

Також у межах обласної програми розвитку кооперативного руху на селі 300 тис. грн виділено кооперативу «Агроселбуд» для придбання пресу для сої. Ним вироблятимуть соєвий шрот для відгодівлі свиней. Користуватимуться цією продукцією всі 18 домогосподарств, тобто понад 40 осіб, які є членами кооперативу. Кооператив «Агроселбуд», окрім відгодівлі тварин, допомагає членам кооперативу 3 оранкою й іншими польовими роботами. Необхідна техніка для цього у підприємства $є$ [10].

22 квітня 2020 р. Уряд ухвалив постанову КМУ № 106 «Про внесення змін до Порядку використання коштів, передбачених у державному бюджеті для надання фінансової підтримки розвитку фермерських господарств». Цією Постановою удосконалюється механізм державної підтримки й кооперативним підприємствам. Зокрема, державна підтримка кооперативам буде реалізуватися за такими напрямами, як:

1) часткова компенсація витрат, пов'язаних із наданням дорадчих послуг;

2) відшкодування сільськогосподарським обслуговуючим кооперативам 70\% вартості (без ПДВ) як на придбання техніки та обладнання, так і на повернення профінансованих за рахунок банківського кредиту коштів;

3) фінансова підтримка для придбання вітчизняного обладнання для виробництва, збирання, зберігання, переробки, визначення якості, сортування та фасування сільськогосподарської продукції та техніки для іiї транспортування.

Прийнята постанова розширить доступ сільськогосподарських кооперативів до державних фінансових ресурсів і створить умови для збільшення не менш ніж на 10 одиниць кількості кооперативів із переробки сільськогосподарської продукції [11].

В Україні у 2019 р. за програмою підтримки фермерських господарств та кооперативів було витрачено бюджетних коштів в сумі 416,9 млн грн, якими скористалося близько 10 тис. фермерів та 2 сільгоспкооперативи [12]. Слід зазначити, що заходи державної підтримки сільськогосподарської кооперації охоплюють усі напрями - від реєстрації до організації збуту продукції. Для кооперативів немає обмежень, вони можуть скористатися одночасно всіма видами субсидій, в тому числі на:

- формування багаторівневої системи кооперації, спрямованої на залучення нових членів у сільськогосподарські кредитні кооперативи, створення кооперативів другого рівня;

- підтримання фінансової стабільності кооперативів (відшкодування витрат на проведення ревізій, обслуговування розрахункового рахунку кооперативу в банках);

- будівництво, реконструкцію та модернізацію виробничих, складських будівель, приміщень, споруд із виробництва, переробки та зберігання сільськогосподарської продукції;

- придбання обладнання, транспортних засобів, техніки і машин;

- технологічний супровід кооперативних ринків, установку нестаціонарних торгових об'єктів для організації сільськогосподарських ярмарків;

- брендування кооперативної продукції.

Окрім державної підтримки, для кооперативів Черкащини передбачено податкові пільги, які забезпечують фінансово-економічну стабільність кооперативів, у тому числі:

- податкові пільги сільськогосподарським кооперативам, які займаються виробництвом харчової продукції та застосовують спрощену систему оподаткування;

- податкові пільги індивідуальним підприємцям членам сільськогосподарських споживчих кооперативів, які використовують патентну систему оподаткування (в частині диференціації потенційно можливого розміру до отримання річного доходу за видами діяльності і ін.);

- податкові пільги кооперативам 3 податку на майно організацій.

Органи державної та виконавчої влади і кооперативи Черкащини працюють над створенням кооперативної торговельної мережі, формуються умови для входу в роздрібну торговельну мережу на основі контрактів, угод, договорів. Продаж кооперативної продукції здійснюють майже 200 підприємств роздрібної торгівлі. Запроваджено практику взаємодії кооперативів із мережевими компаніями. Одним із пріоритетних напрямів політики Черкаської області є залучення населення у виробничі відносини через створення кооперативних підприємств різної спеціалізації [10]. 
Отже, кооперативний рух може і повинен стати основою сталого розвитку сільських територій.

На нашу думку, успіх розвитку кооперації на Черкащині залежить від таких чинників, як:

- системна підтримка кооперативів (нормативноправова, фінансова, інституційна, методична, інформаційна, роз'яснювальна, матеріально-технічна);

- створення багаторівневої системи підтримки кооперації;

- міжвідомчий підхід, комбінування ресурсів програм розвитку сільського господарства, малого бізнесу, соціального захисту, підтримки сільської молоді;

- використання адміністративного ресурсу на всіх рівнях: регіон, район, сільські адміністрації, робота 3 потенційними лідерами і ретельний відбір членів кооперативу;

- комбінування можливостей обслуговуючої і кредитної кооперації для розвитку бізнесу;

- використання кооперування як для підвищення доходів та зайнятості сільського населення (рішення соціальних завдань), так і для розвитку потенціалу середніх і великих сільгосптоваровиробників для виведення їх на новий рівень;

- підтримка товаровиробника одночасно з розширенням каналів для збуту продукції (ринки, бюджетна сфера);

- створення сприятливих умов для роботи бізнесу за допомогою асоціацій сільгосптоваровиробників.

Результатом застосування комплексних заходів державної та регіональної підтримки сільськогосподарської кооперації має стати підвищення рівня довіри сільського населення до кооперативних форм господарювання.

Висновки. Значення сільськогосподарських кооперативів у сучасній економіці важко переоцінити, оскільки вони $є$ вагомою часткою валового національного продукту (ВНП) і зайнятості населення.
Проведені нами дослідження показали, що розвиток кооперації буде успішним у тому разі, коли починатиметься зі створення сільськогосподарського споживчого кредитного кооперативу. Це пояснюється більш універсальним характером послуг, що надаються сільськогосподарським споживчим кредитним кооперативом.

Розвиток кооперативів (переробних, збутових, обслуговуючих) стримується тим, що комерційні банки в принципі не кредитують (і в найближчому майбутньому, на нашу думку, не будуть кредитувати) такого роду некомерційні підприємства. Таким чином, формування кооперативів безпосередньо залежить від розвитку сільськогосподарської споживчої кредитної кооперації. Також нині необхідним є вжиття заходів щодо впровадження на всій території України найкращих регіональних практик управління системою сільськогосподарської кооперації та її розвитку.

Сьогодні українська модель кредитної кооперації може наслідувати досвід Австралії та Бразилії в плані концентрації та виживання в умовах тривалої економічної кризи [2].

Стимулом для розвитку кредитної кооперації є підтримка на поповнення фондів фінансової взаємодопомоги. Розширення кредитної кооперації здійснюється за двома напрямами: залучення особистих підсобних господарств і створення кооперативів II рівня. Успішно використовується великими кредитними кооперативами й механізм асоційованого членства в регіональному фонді підтримки підприємництва по Черкаській області. Це дає змогу кооперативам збільшити іхній капітал та розширює для них доступ до пільгових позик.

Тому подальші дослідження, на нашу думку, мають бути спрямовані саме на вивчення та дослідження питань розвитку кредитної кооперації як однієї зі складових частин кооперативного руху.

\section{Список літератури:}

1. Шпикуляк О.Г., Малік М.Й. Інституціональний аналіз розвитку підприємництва в аграрному секторі економіки: методичний аспект. Економіка АПК, 2019. № 6. С. 73-82.

2. Арсьонова A.O. Теоретичні підходи формування досвіду кооперативного руху, 2020. URL: http://www.rusnauka.com/ 16_ADEN_2011/Economics/3_88120.doc.htm (дата звернення: 26.04.2020).

3. Зіновчук В.В. Організаційно-правові засади становлення сільськогосподарської кооперації в Україні. Вісник БУМіБ, 2014. № 3 (27), Т.2. С. 45-50.

4. Кучерява К.Я. Кооперація в аграрному секторі економіки України як об'єкт державного регулювання. Актуальні проблеми державного управління, 2014. № 2. С. 34-42.

5. Індекс виробництва валової сільськогосподарської продукції в області перевищив 100 відсотків. Прочерк, Про цее говорять Черкаси. 05 серпня 2019, URL: https:/procherk.info/news/7-cherkassy/74537-indeks-virobnitstva-valovoyisilskogo spodarskoyi-produktsiyi-v-oblasti-perevischiv-100-vidsotkiv (дата звернення: 26.04.2020).

6. На Черкащині найбільше сільськогосподарських кооперативів в Україні. 2019. Черкаська обласна державна адміністрація. Офіиійний портал. URL: http://ck-oda.gov.ua/na-cherkaschyni-najbilshe-silskohospo darskyh-kooperatyviv-vukrajini/ (дата звернення: 30.04.2020).

7. Малік М.Й., Лузан Ю.Я. Проблемні питання розвитку кооперації та інтеграційних відносин в АПК. Економіка АПК. 2010. № 3. С. 3-9.

8. Собкевич О., Русан В., Юрченко А. Щодо першочергових напрямів підтримки розвитку сільськогосподарської кооперації в Україні. Аналітична записка. 2019. Національний інститут стратегічних досліджень. URL: https://niss.gov.ua/doslidzhennya/ekonomika/schodo-pershochergovikh-napryamiv-pidtrimki-rozvitku-silskogo spodarskoi (дата звернення: 29.04.2020). 
9. Стартувала кампанія з інформування населення області про фінансований Свропейським Союзом проект 3 розвитку кооперації, 2015. Черкаська обласна державна адміністрація. Офіиійний портал. URL: http://ck-oda.gov.ua/ startuvala-kampaniya-z-informuvannya-naselennya-oblasti-pro-finansovanyj-evropejskym-soyuzom-proekt-z-rozvytkukooperatsiji/ (дата звернення: 26.04.2020).

10. На контролі - виконання обласної програми підтримки розвитку сільськогосподарських обслуговуючих кооперативів, 2020. Черкаська обласна рада. Офіиійний caüm. URL: https://www.oblradack.gov.ua/na-kontroli-vikonannyaoblasnoi-programi-pidtrimki-rozvitku-silskogospodarskikh -obslugovuyuchikh (дата звернення: 26.04.2020).

11. Про внесення змін до Порядку використання коштів, передбачених у державному бюджеті для надання фінансової підтримки розвитку фермерських господарств: Постанова від 30 січня 2019 р. № 126. Кабінет Міністрів України. URL: https://zakon.rada.gov.ua/laws/show/126-2019-\%D0\%BF (дата звернення: 27.04.2020).

12. Уряд визначив напрямки підтримки фермерських господарств та кооперативів. 2020. Міністерство розвитку економіки, торгівлі та сільського господарства України. Oфiuiйний caŭm. URL: https://www.me.gov.ua/News/ Detail?lang=uk-UA\&id=bde446c6-2e93-4447-bc81-d1d2dd7ad5d1\&title=UriadViznachivNapriamkiPidtrimkiFermerskikh GospodarstvTaKooperativiv (дата звернення: 26.04.2020).

13. Sakovska O., Shpykuliak O., Ushkarenko Iu., Chmut A. Socio-economic institutions for development of cooperation. Фінансово-кредитна діяльність: проблеми теорї та практики. 2018. Vol. 4. № 27. Р. 513-521.

14. Sakovska O., Shpykuliak O. State regulation of the functioning and development of agricultural cooperatives in the grain market. Proceedings of the $33^{\text {rd }}$ International Business Information Management Association Conference, IBIMA 2019: Education Excellence and Innovation Management through Vision 2020. 33 ${ }^{\text {rd }}$ IBIMA Conference: 10-11 April 2019 Granada, Spain. Editor Khalid S. Soliman. 2019. P. 8316-8321.

\section{References:}

1. Shpykuliak O.H., Malik M.I. (2019). Instytutsionalnyi analiz rozvytku pidpryiemnytstva $\mathrm{v}$ ahrarnomu sektori ekonomiky: metodychnyi aspekt. [Institutional analysis of entrepreneurship development in agricultural sector of economy: methodical aspect]. Economy AIC, vol. 6, pp. 73-82.

2. Arsionova A.O. (2020). Teoretychni pidkhody formuvannia dosvidu kooperatyvnoho rukhu [Theoretical Approaches for Forming the Cooperative Movement Experience]. Available at: http://www.rusnauka.com/16_ADEN_2011/ Economics/3_88120.doc.htm (accessed: 26.04.2020).

3. Zinovchuk V.V. (2014). Orhanizatsiino-pravovi zasady stanovlennia silskohospodarskoi kooperatsii v Ukraini [Organizational and legal bases of formation of agricultural cooperation in Ukraine]. BUMiB Bulletin, vol. 3(27), № 2, pp. 45-50.

4. Kucheriava K.Ia. (2014). Kooperatsiia v ahrarnomu sektori ekonomiky Ukrainy yak obiekt derzhavnoho rehuliuvannia [Cooperation in the agricultural sector of the Ukrainian economy as an object of state regulation]. Actual Problems of Public Administration, № 2, pp. 34-42.

5. The gross agricultural production index in the region exceeded 100 percent (2019). Dash. This is what Cherkasy is saying, August 05. Available at: https://procherk.info/news/7-cherkassy/74537-indeks-virobnitstva-valovoyi-sils kogospodarskoyiproduktsiyi-v-oblasti-perevischiv-100-vidsotkiv (accessed: 26.04.2020).

6. In the Cherkasy region the largest agricultural cooperatives in Ukraine (2020). Available at: http://ck-oda.gov.ua/ na-cherkaschyni-najbilshe-silskoho spodarskyh-kooperatyv iv-v-ukrajini/ (accessed: 30.04.2020).

7. Malik M.I., Luzan Yu.I. (2010). Problemni pytannia rozvytku kooperatsii ta intehratsiinykh vidnosyn v APK [Problems of development of cooperation and integration relations in agriculture]. Economy AIC, vol. 3, pp. 3-9.

8. Sobkevych O., Rusan V., Yurchenko A. (2019). Shchodo pershocherhovykh napriamiv pidtrymky rozvytku silskohospodarskoi kooperatsii v Ukraini [Concerning priority directions of support of development of agricultural cooperation in Ukraine]. National Institute for Strategic Studies. Available at: https://niss.gov.ua/doslidzhennya/ekonomika/ schodo-pershocherg ovikh-napryamiv-pidtrimki-rozvitku-silskogospodarskoi (accessed: 29.04.2020).

9. A campaign to raise awareness of the region's population about the European Union-funded Cooperative Development Project (2015). Available at: http://ck-oda.gov.ua/startuvala-kampaniya-z-informuvannya-naselennya-oblasti-profinansovanyj-evropejskym-soyuzom-proekt-z-rozvytku-kooperatsiji/ (accessed: 26.04.2020).

10. On the control - implementation of the regional program of support for the development of agricultural service cooperatives (2020). Available at: https://www.oblradack.gov.ua/na-kontroli-vikonannya-oblasnoi-programi-pidtri mkirozvitku-silskogospodarskikh-obslugovuyuchikh (accessed: 26.04.2020).

11. Decree «On amendments to the Procedure of using the funds provided in the state budget for providing financial support for the development of farms», (2019). Cabinet of Ministers of Ukraine. Available at: https://zakon.rada.gov.ua/laws/ show/126-2019-\%D0\%BF (accessed: 27.04.2020).

12. The government has identified areas for support for farms and cooperatives (2020). Available at: https://www.me.gov.ua/ News/Detail?lang= uk-UA\&id=bde446c6-2e93-4447-bc81-d1d2dd7ad5d1\&title=UriadViznachiv NapriamkiPidtrimkiFermers kikhGospodarstvTaKooperativiv (accessed: 26.04.2020).

13. Sakovska O., Shpykuliak O., Ushkarenko Iu. and Chmut A. (2018). Socio-economic institutions for development of cooperation. Financial and credit activities: problems of theory and practice, vol. 4, no. 27, pp. 513-521.

14. Sakovska O., Shpykuliak O. (2019) State regulation of the functioning and development of agricultural cooperatives in the grain market. Proceedings of the $33^{\text {rd }}$ International Business Information Management Association Conference, IBIMA 2019: Education Excellence and Innovation Management through Vision 2020. 33 ${ }^{\text {rd }}$ IBIMA Conference: 10-11 April 2019 Granada, Spain. Editor Khalid S. Soliman. pp. 8316-8321. 


\section{СОСТОЯНИЕ И ПЕРСПЕКТИВЫ РАЗВИТИЯ СЕЛЬСКОХОЗЯЙСТВЕННЫХ КООПЕРАТИВОВ ЧЕРКАССКОЙ ОБЛАСТИ}

В статье проанализировано состояние, специффика и перспективы развития сельскохозяйственных кооперативов Черкасской области. Отмечено, что в современных экономических условиях объединение товаропроизводителей на условиях кооперации приобретает особую актуальность. Установлено, что основными иелями развития сельскохозяйственной кооперации на территории Черкасской области является создание благоприятных социально-экономических условий для развития инфраструктуры села, совершенствование системы заготовки продукции, переработки сельскохозяйственной продукции. Обозначено, что в области осуществляется комплексный подход к развитию кооперации, который включает организационные, финансовые механизмы и объединение усилий всех уровней власти. Определены принципиальные основы развития сельскохозяйственных кооперативов на территории Черкасской области. Разработана трехуровневая система управления развитием кооперации на региональном уровне. Обозначены ключевые меры государственной поддержки сельскохозяйственной кооперации в области и исследованы пути их реализащии. Указано, что результатом применения комплексных мер государственной и региональной поддержки сельскохозяйственной кооперации должно стать повышение уровня доверия сельского населения к кооперативным формам хозяйствования.

Ключевые слова: кооператив, сельское хозяйство, сельская территория, регион, государство, развитие.

\section{STATUS AND PROSPECTS OF THE DEVELOPMENT OF AGRICULTURAL COOPERATIVES IN CHERKASY REGION}

Agricultural cooperation is one of the key components of ensuring food security of Ukraine and plays a significant role in strengthening the economic potential of the region, improving economic conditions and creating incentives for growth of commodity products. Cooperative enterprises form the basis of rural territory development and play a significant role not only in accelerating the growth of the agro-industrial complex, but also in addressing the most important social problems of the village: providing employment to the rural population; promote the preservation of the traditional way of life; being the source of replenishment of local budgets. Therefore, one of the priority areas for the development of the Ukrainian economy is the revival and sustainable development of the agricultural cooperation system. This aspect determines the relevance of the article, defines the purpose and objectives of the study. The purpose of the article is to analyze the condition and determine the key principles for the development of agricultural cooperatives of Cherkasy region. The article analyzes the condition and particularity of the development of agricultural cooperatives of Cherkasy region. It is stated that under the current economic conditions, the association of producers under cooperative conditions becomes especially relevant. It is established that the main goals of the development of agricultural cooperation in the territory of Cherkasy region is to create favorable socio-economic conditions for the development of village infrastructure, improvement of the system of harvesting products, recycling of agricultural products. It is ascertained that in the region a comprehensive approach to the development of cooperation is being implemented, which includes organizational, financial mechanisms and uniting efforts of all levels of government. The fundamental principles of development of agricultural cooperatives on the territory of Cherkasy region are outlined. A three-level system for managing the development of cooperation at the regional level has been developed. The key measures of state support of agricultural cooperation in the region are identified and ways of their realization are investigated. It is pointed out that the implementation of comprehensive measures of state and regional support for agricultural cooperation should become increase of the level of confidence of rural population in cooperative forms of management.

Key words: cooperative, agriculture, rural territory, region, state, development. 